\title{
Analysis of High-Rise Building and its Behaviour Due to Shear Wall at Different Location and in Different Seismic Zones
}

\author{
Mr. Basavalingappa \\ Asst-Professor \\ Department of Civil Engineering RYMEC \\ Ballari
}

\author{
Mr. Anil Kumar B \\ PG Student \\ Department of Civil Engineering RYMEC \\ Ballari
}

\begin{abstract}
:-
India at present is fast growing economy \&Population $g$ rowthwill increase demands of land.

To construct high rise structure are more

advantage to provide they demands in construction indus try.After many practical studies it has shown that use of lateral loadresistingsystems in the building configuration has tremendouslyimproved the per formance of the structure in earthquake. Framed \& Shear walls are mainly flexural members and usually provided in high rise buildings to avoid the total collapse of the

high rise buildings under seismic forces. Shear walls are provided in elevator Authors Name/s per core, face \& corner of the structure to increase the stiffens \& behaviour of structure., there by resisting the horizontal and vertical forces effectively. In the present study, analysis of RCC building has been carried out by changing the locations of shear walls in the building. Also, the effect of variations in seismic zones as per IS codes has been presented. The seismic analysis performed is dynamic response spectrum method as per IS1893-2016 using the well-known analysis and design software ETABS15.0. Seismic performance of the building has been investigated based on parameters such as time period, storey displacements, storey drift \& base shear along both the direction of the structure.

From the investigation conclude the shear wall impacts in high rise structural system with respective all seismic zones.
\end{abstract}

Keywords-Seismic, ETABS, storey, Indian Standard, high

\section{INTRODUCTION}

India at present is fast growing economy,which brings about demands in increaseof infrastructure facilitiesalong with the growth of population.The demand of land in urban regions is increasing day by day.It is imperative that land available for farming andagriculture remains intact. To cater the land demand in these regions, vertical development is the only option. This type of development brings challenges to counteract additional lateral loads due to wind and earthquake. This demands changes in the current structural system which needs to be implemented to resist these forces. Much research has been carried which describes the suitability of various lateral load resisting system against deformation and shear exerted due to the earthquake and windforces.
The seismic movement of the ground causes the structure to vibrate and causes structural deformity in the building. Different parameters regarding this deformity like frequency of vibration, time period and amplitude are of significant importance and defines the overall response of the structure. This overall response also depends on the distribution of seismic forces within the structure which again depends on the method which is used to calculate this distribution. Different methods of 3-Dimensional dynamic analysis of structures have become more efficient in use along with the development of technology.

\section{MAJOR STRUCTURALSYSTEMS}

RIGID FRAMESYSTEM:

'Consist of column and girders joined by moment resistant connections. The lateral stiffness of a rigid-frame bent depends on the bending stiffness of the columns, girders and connections in the plane of the bent

\section{RIGID FRAME WITH SHEARWALL:}

It is a vertical continuous stiffening element, that deform in bending mode. It is Used in reinforced concrete buildings and suited to residential buildings and hotels.

When shear walls are combined with rigid frame the walls, which tend to deflect in flexural configuration, and the frames, which tend to deflect in shear modeare constrained to adopt a common deflected shape by the horizontal rigidity of the girders and slabs.

Consequences, the walls and frames interact horizontally, especially at the top to produce a stiffer and stronger structure.

The interacting wall-frame combination is appropriate for building in the 20 to 40 stories range, well beyond that of rigid frames or shear walls alone.

\section{SHEAR WALL WITHOPENING}

Framed structures with shear walls are frequently adopted as the structural system for high rise buildings, the openings may be window, door types openings as described previously. The behaviour of wall will change, these change will occur in deflection, bending moment, shear force, and the stress in walls. Openings may be small or large depending on the function of the building. In residential 
building, opening like window, door, and corridor are sufficient whereas for special building like cinema theatres, function hall, hotels, community halls, it requires larger openings to meet the requirements

\section{OUTRIGGERSYSTEM}

Outriggers are connected directly to the core and to exterior columns. Used in reinforced concrete and steel buildings. Outriggers restrain the rotation of the core and convert part of the moment in the core into a vertical couple at the columns.

The outrigger structural systems not only proficient in controlling the top displacements but also play substantial role in reducing the inter storey drifts

\section{The beneficial action is a function of two factors:}

1. The stiffness of the outrigger (Varies inversely with the outrigger distance from the base)

2. Its location in the building.

STRUCTURAL SYSTEMS FOR DIFFERENT HEIGHTS:

\begin{tabular}{|l|l|}
\hline Height & Suggested System \\
\hline 10 stories $(35 \mathrm{~m})$ & Rigid Frame, Shear Wall \\
\hline 20 stories $(70 \mathrm{~m})$ & Shear Wall, Outrigger \\
\hline 30 stories $(105 \mathrm{~m})$ & $\begin{array}{l}\text { Rigid Frame with Shear Wall, } \\
\text { Outrigger }\end{array}$ \\
\hline 40 stories $(140 \mathrm{~m})$ & $\begin{array}{l}\text { Rigid Frame with Shear Wall, } \\
\text { Outrigger }\end{array}$ \\
\hline 50 stories $(175 \mathrm{~m})$ & Outrigger \\
\hline 60 stories $(210 \mathrm{~m})$ & Outrigger \\
\hline
\end{tabular}

Table 1: structural systems for different heights

\section{ROLE OF SHEAR WALL}

To resist these lateral forces, shear walls are specially designed structural walls included in the buildings to resist horizontal forces that are induced in the plane of the wall due to wind, earthquake and other forces.

\section{ADVANTAGES OF SHEARWALL}

It provides adequate strength to resist large lateral loads without excessive additional cost.

$>$ It provides adequate stiffness to resist lateral displacement within permissible limits, thus reducing risk of nonstructural damage.

$>$ They should be located such a way that they also act as functional walls and do not interfere with the architectural of the building.

> Shear wall should be placed along both the axis, so that lateral stiffness can be provided in both directions, particularly in the case of square buildings.

To avoid torsion effect shear wall should be placed symmetrically about the axis.

\section{FUNCTION OF SHEAR WALL}

The main function of a Shear Wall can be described as follows.

$>$ Providing Lateral Strength to building: Shear Wall must provide lateral shear strength to the building to resist the horizontal earthquake forces, wind forces and transfer these forces to the foundation.

Providing Lateral Stiffness to building: Shear Walls provide large stiffness to building in the direction of their orientation, which reduces lateral sway of the building and thus reduces damage to structure

STRUCTURAL ANALYSIS METHODS TO UNDERSTAND THE BEHAVIOUR OF STRUCTURE

Few of the methods are explain below:

EQUIVALENT STATICMETHOD:

This approach defines a series of forces acting on a building to represent the effect of earthquake ground motion. It assumes that the building responds in its fundamental mode. For this to be true, the building must be low-rise and must not twist significantly when the ground moves. As per this method first the design base shear shall be computed for the building as a whole. Then the base shear shall be distributed to the various floor levels at the corresponding centre of mass and finally the design seismic force shall be distributed to individual lateral load resisting elements through structural analysis considering the floor diaphragm action. This method

is applicable for regular building with height less than $15 \mathrm{~m}$ in seismic zone II as per IS code 1893-2016.

\section{RESPONSE SPECTRUM METHOD:}

The response spectrum represents an envelope of upper bound responses, based on several different ground motion records. For the purpose of seismic analysis, the design spectrum given in IS: 18932016 is used. This spectrum is based on strong motion records of eight Indian earthquakes. This method is an elastic dynamic analysis approach that relies on the assumption that dynamic response of the structure may be found by considering the independent response of each natural mode of vibration and then combining the response of each in same way. This is advantageous in the fact that generally only few of the lowest modes of vibration have significance while calculating moments, shear and deflections at different levels of the building.

\section{DYNAMIC ANALYSIS:}

Static Analysis method requires less effort because except for the fundamental period, the periods and shapes of higher natural modes of vibration are not considered while in dynamic analysis the periods and shapes of higher natural modes of vibration are also considered addition to fundamental periods which are considered in static analysis. Dynamic method as compared to static method mainly observed base shear is less in static than dynamic the displacement will be less in dynamic and also the moment hence dynamic method is used for analysis. 


\section{MainObjectives}

1.To determine the optimum position of shear wall by consider architectural plan of the building.

2.To analyze behavior of structurer due to dynamic load with all seismic zones.

3.To study the structures with respect to story drift ratio, story displacement, time period, base shear\&forces.

4.The present study is limited to analysis of 20 story of R.C.C. Buildings

5.To provide guide lines for structural engineer on the serviceability \& economic aspects, that could be obtained by using shearwall.

\section{Scope of the presentwork}

1. In the present work four structural system has been considered i.e., one RCC frame structure without shear wall and three structure with shearwall.

2. All models were analyzed using and dynamic response spectrum method as per IS1893-2016 specifications using ETABS software.

\section{METHODOLOGY}

The term building in Civil Engineering is used to mean a structure having various components like foundation, walls, columns, floors, roofs, doors, windows, ventilators, stairs lifts, various types of surface finishes etc. Structural analysis and design is used to produce a structure capable of resisting all applied loads without failure during its intended life. Prior to the analysis and design of any structure, necessary information regarding supporting soil has to be collected by means of geotechnical investigation. A geotechnical site investigation is the process of collecting information and evaluating the conditions of the site for the purpose of designing and constructing the foundation for a structure. Structural engineers are facing the challenges of striving for most efficient and economical design with accuracy in solution while ensuring that the final design of a building and the building must be serviceable for its intended function over its design life time. Now a days various software packages are available in market for analyzing and designing practically all types of structures viz. RISA, STAADPRO, ETABS, STRUDL, MIDAS, SAP and RAM etc.

\section{MODELLING AND ANALYSIS}

Modelling allows planners, designers and engineers to redesign routes based on value engineering principles and changing construction techniques.

Modelling and analysis of building is necessary for various components of structure with cost efficient bridge to overcome all type of disasters, to develop some design which is most efficient in a way to carry high loads at a very low fabrication cost etc. There are many modelling and design software's are available in construction field. In this research work AutoCAD, Etabs, MS office are effectively utilized.

\section{MODEL DATA}

General details of the building

Structure: RCC framed structure with \& without shear wall.

Plan Dimension: $35 \mathrm{~m} \times 25 \mathrm{~m}$ along $\mathrm{X}$ and $\mathrm{Y}$ directions

Grid Spacing: As per plan

No. of storey.: Basement +12

Storey height 1) Basement storey: $3.2 \mathrm{~m}$

2)Ground \&Typical storey: $3.0 \mathrm{~m}$

Type of building use: Commercial

Material Property

Grade of concrete: M40

Grade of Steel: Fe HYSD550

Structural member details

Column :300x750 mm

Beam :230x600mm

Slab-150mm

Load Intensities

Floor finishes: $1.50 \mathrm{KN} / \mathrm{m}^{2}$

Live Load: $3.0 \mathrm{KN} / \mathrm{m}^{2}$

Wind Load Parameters

Wind speed: $50 \mathrm{~m} / \mathrm{sec}$

Terrain category: 2

Seismic Load Parameters

Zones: II, III, IV, V

Importance Factor(I): 1

Response Reduction Factor(R):5

Soil Type: medium

\section{MODEL DESCRIPTION}

The modelling of the 1 basement +12 , storey building has been done. These buildings are modelled with RCC structural elements. The models are further studied for different Shear wall members. Here are the different types of model shown for the easy assessment

\section{BASE MODELS}

MODEL 1: RCC frame without shear wall

MODEL 2: RCC frame with shear wall -periphery of building

MODEL 3: RCC frame without shear wall-corners of the building

MODEL 4: RCC frame without shear wall-Face of thebuilding

ANALYSIS

\section{PURPOSE OF USING DYNAMIC ANALYSIS}

Dynamic analysis is related to the inertia forces developed by a structure when it is excited by means of dynamic loads applied suddenly (e.g., wind blasts, explosion and earthquake). A static load is one which varies very slowly with time. A dynamic load is one which changes with time fairly quickly in comparison to the structure's natural frequency. If it changes slowly, the structure's response may be determined with static analysis, but if it varies quickly (relative to the structure's ability to respond), theresponse must be determined with a dynamic analysis. 
Dynamic analysis of structure is a part of structural analysis in which behaviour of flexible structure subjected to dynamic loading is studied. Dynamic load always changes with time. Dynamic load comprises of wind, live load, earthquake load etc. Thus, in general we can say almost all the real life problems can be studied dynamically. Types of seismic analysis used in this study are Equivalent lateral force method (Static linear method) and Response spectrum method.

\section{RESPONSE SPECTRUM ANALYSIS}

This method is applicable for those structures where modes other than the fundamental one affect significantly the response of the structure. In this method the response of Multi-Degree-of-Freedom (MDOF) system is expressed as the superposition of modal response, each modal response being determined from the spectral analysis of single - degree-of- freedom (SDOF) system, which is then combined to compute total response. Modal analysis leads to the response history of the structure to a specified ground motion; however, the method is usually used in conjunction with a response spectrum. A response spectrum is simply a plot of the peak or steadystate response (displacement, velocity or acceleration) of a series of oscillators of varying natural frequency that are forced into motion by the same base vibration or shock. The resulting plot can then be used to pick off the response of any linear system, given its natural frequency of oscillation. One such use is in assessing the peak response of buildings to earthquakes. The science of strong ground motion may use some values from the ground response spectrum (calculated from recordings of surface ground motion from seismographs) for correlation with seismic damage. If the input used in calculating a response spectrum is steady- state periodic, then the steady-state result is recorded. Damping must be present, or else the response will be infinite.

For transient input (such as seismic ground motion), the peak response is reported. Some level of damping is generally assumed, but a value will be obtained even with no damping. Response spectra can also be used in assessing the response of linear systems with multiple modes of oscillation (multi-degree of freedom systems), although they are only accurate for low levels of damping. Modal analysis is performed to identify the modes, and the response in that mode can be picked from the response spectrum. This peak response is then combined to estimate a total response. A typical combination method is the square root of the sum of the squares (SRSS) if the modal frequencies are not close. he result is typically different from that which would be calculated directly from an input, since phase information is lost in the process of generating the response spectrum. The main limitation of response spectra is that they are only universally applicable for linear systems. Response spectra can be generated for non-linear systems, but are only applicable to systems with the same nonlinearity, although attempts have been made to develop nonlinear seismic design spectra with wider structural application.

\begin{tabular}{|c|c|c|c|c|}
\hline \multicolumn{5}{|c|}{ TIME PERIOD (sec) } \\
\hline MODES & $\begin{array}{l}\text { Model } \\
1\end{array}$ & $\begin{array}{l}\text { Model } \\
2\end{array}$ & $\begin{array}{l}\text { Model } \\
3\end{array}$ & $\begin{array}{l}\text { Model } \\
4\end{array}$ \\
\hline 1 & 1.658 & 0.274 & 0.917 & 1.123 \\
\hline 2 & 1.241 & 0.219 & 0.773 & 0.893 \\
\hline 3 & 1.105 & 0.136 & 0.531 & 0.758 \\
\hline 4 & 0.551 & 0.101 & 0.239 & 0.314 \\
\hline 5 & 0.409 & 0.077 & 0.212 & 0.262 \\
\hline 6 & 0.36 & 0.071 & 0.13 & 0.204 \\
\hline 7 & 0.326 & 0.061 & 0.124 & 0.157 \\
\hline 8 & 0.239 & 0.057 & 0.108 & 0.134 \\
\hline 9 & 0.231 & 0.053 & 0.088 & 0.105 \\
\hline 10 & 0.206 & 0.052 & 0.075 & 0.097 \\
\hline 11 & 0.179 & 0.051 & 0.071 & 0.088 \\
\hline 12 & 0.167 & 0.049 & 0.065 & 0.084 \\
\hline
\end{tabular}

Table 2 TIME TABLE

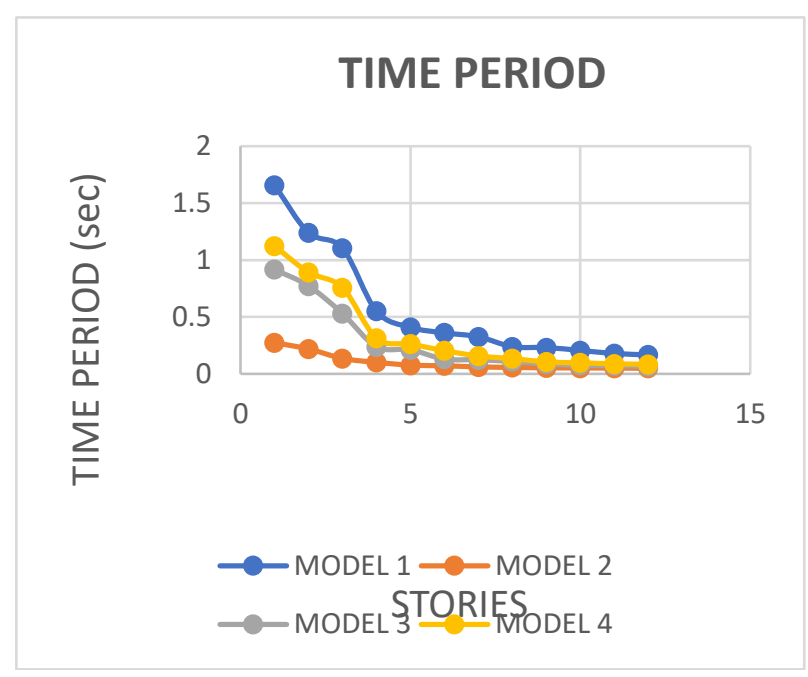

Graph 1 TIME PERIOD

According to IS 1893-2016 "the total number of modes to be considered in the analysis should satisfy the condition that the sum of the modal mass of all the modes selected is $90 \%$ the seismic mass". Sixteen modes are considered for the analysis and sum of modal mass of all modes found to be greater than $90 \%$ of the total seismic mass

The maximum time period obtained is $1.658 \mathrm{sec}$ for Model 1. The time period is $0.274,0.917,1.123$ seconds for Model-2, Model-3, Model-4 respectively, which is lesser than Model-1. Whereas, the least time period obtained is 0.274 sec for Model-2 compared to all the other models indicating that it is stiffer model than other models.

\section{BASE SHEAR}

The percentage reduction is found to be similar for all seismic zones. 


\begin{tabular}{|c|c|l|l|}
\hline \multicolumn{4}{|c|}{ BASE SHEAR Zone II (KN) } \\
\hline Along X Direction & Along Y direction \\
\hline MODEL & & MODEL & \\
\hline MODEL 1 & 1139.472 & MODEL 1 & 1214.656 \\
\hline MODEL 2 & 5829.24 & MODEL 2 & 4104.672 \\
\hline MODEL 3 & 1119.576 & MODEL 3 & 1087.32 \\
\hline MODEL 4 & 1646.656 & MODEL 4 & 1722.536 \\
\hline \multicolumn{5}{|c}{ Table 3 Base shear zone II } \\
\hline
\end{tabular}
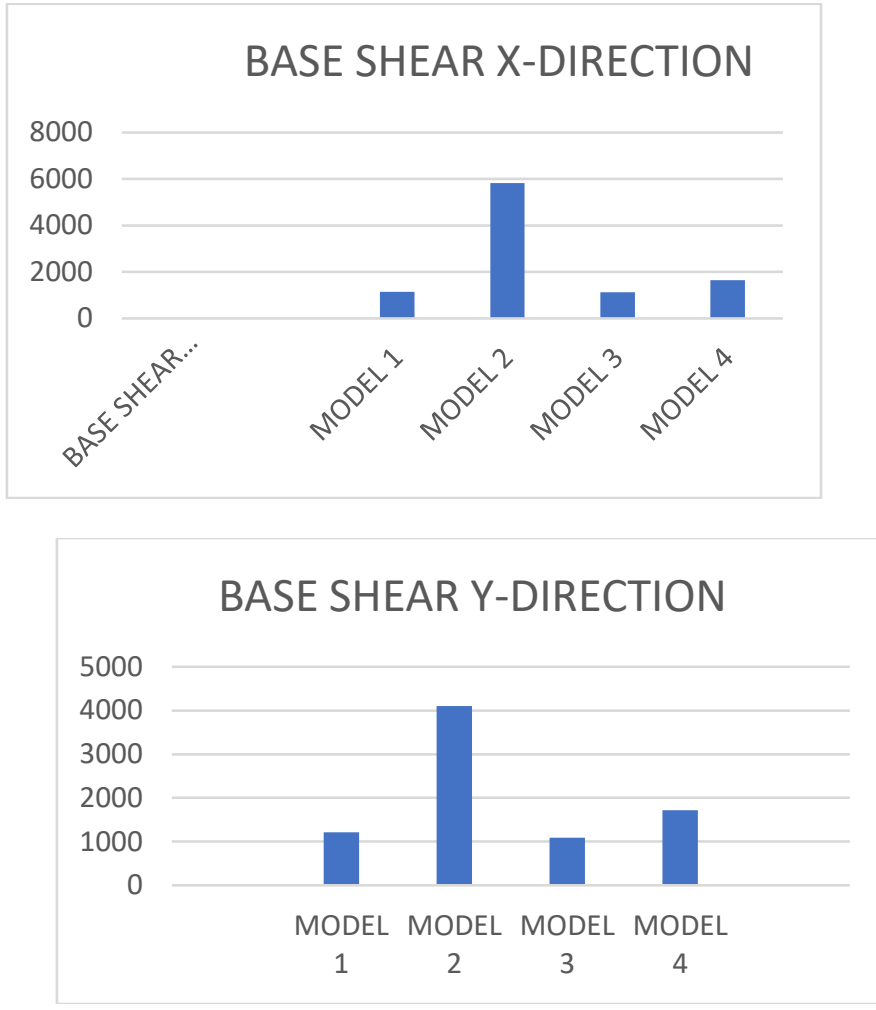

Graph 2 Base shear zone II

\begin{tabular}{|c|l|l|l|}
\hline \multicolumn{4}{|c|}{ BASE SHEAR Zone III (KN) } \\
\hline Along X Direction & \multicolumn{2}{l|}{ Along Y direction } \\
\hline MODEL & & MODEL & \\
\hline MODEL 1 & 1281.906 & MODEL 1 & 1366.488 \\
\hline MODEL 2 & 6557.895 & MODEL 2 & 4617.756 \\
\hline MODEL 3 & 1259.523 & MODEL 3 & 1223.235 \\
\hline MODEL 4 & 1852.488 & MODEL 4 & 1937.853 \\
\hline
\end{tabular}

Table 4 Base shear zone III

\section{BASE SHEAR X-DIRECTION}

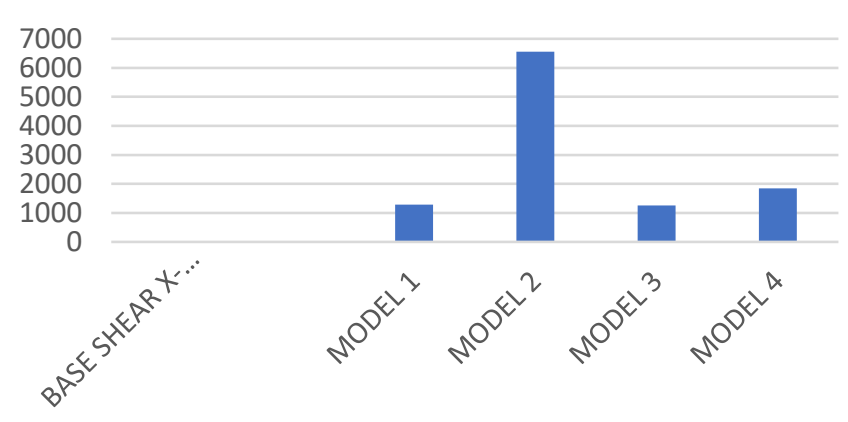

\section{BASE SHEAR Y-DIRECTION}

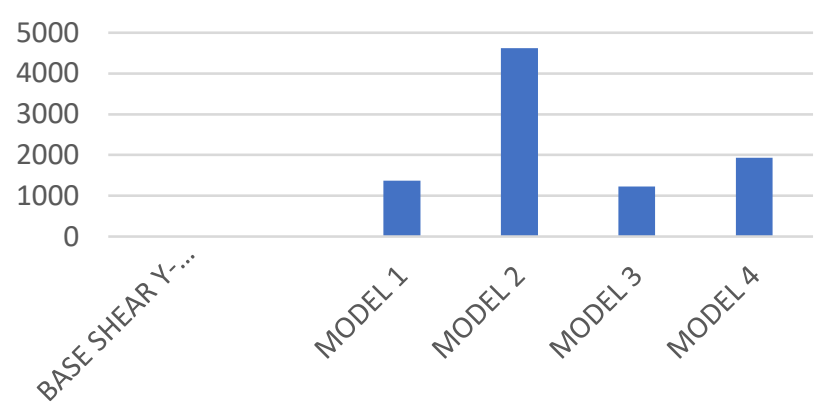

Graph 3 Base shear zone III

\begin{tabular}{|c|l|l|l|}
\hline \multicolumn{4}{|c|}{ BASE SHEAR Zone IV (KN) } \\
\hline Along X Direction & \multicolumn{2}{l|}{ Along Y direction } \\
\hline MODEL & & MODEL & \\
\hline MODEL 1 & 1424.34 & MODEL 1 & 1518.32 \\
\hline MODEL 2 & 7286.55 & MODEL 2 & 5130.84 \\
\hline MODEL 3 & 1399.47 & MODEL 3 & 1359.15 \\
\hline MODEL 4 & 2058.32 & MODEL 4 & 2153.17 \\
\hline
\end{tabular}

Table 5 Base shear zone IV

\section{BASE SHEAR X-DIRECTION}

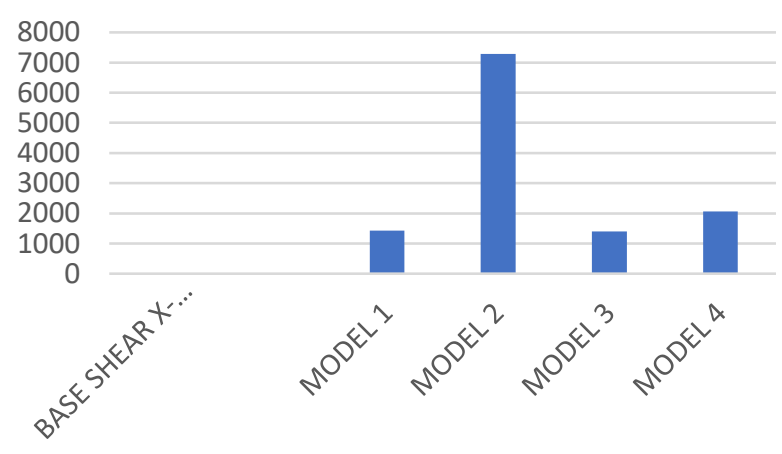




\section{BASE SHEAR Y-DIRECTION}

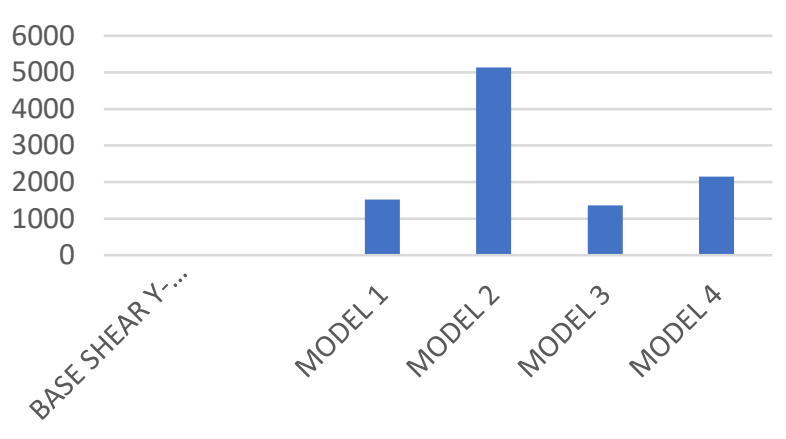

Graph 4 Base shear zone IV BASE SHEAR Zone V (KN)

\begin{tabular}{|c|r|l|r|}
\hline \multicolumn{2}{|c|}{ Along X Direction } & \multicolumn{2}{l|}{ Along Y direction } \\
\hline MODEL & & MODEL & \\
\hline MODEL 1 & 1780.425 & MODEL 1 & 1897.9 \\
\hline MODEL 2 & 9108.188 & MODEL 2 & 6413.55 \\
\hline MODEL 3 & 1749.338 & MODEL 3 & 1698.938 \\
\hline MODEL 4 & 2572.9 & MODEL 4 & 2691.463 \\
\hline
\end{tabular}

Table 6 Base shear zone $V$

\section{BASE SHEAR X-DIRECTION}

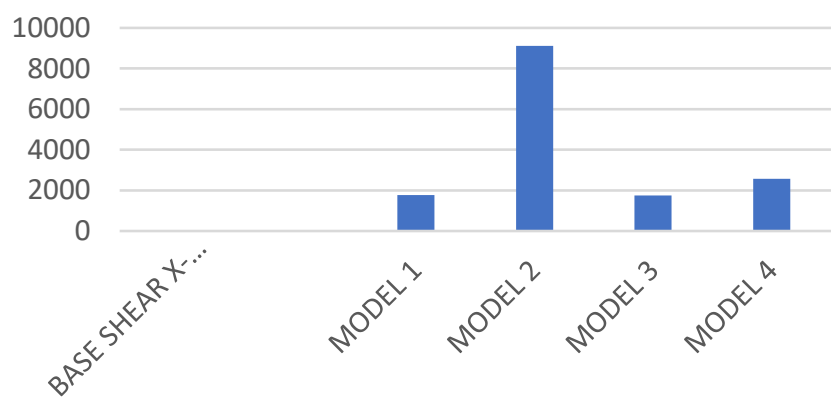

\section{BASE SHEAR Y-DIRECTION}

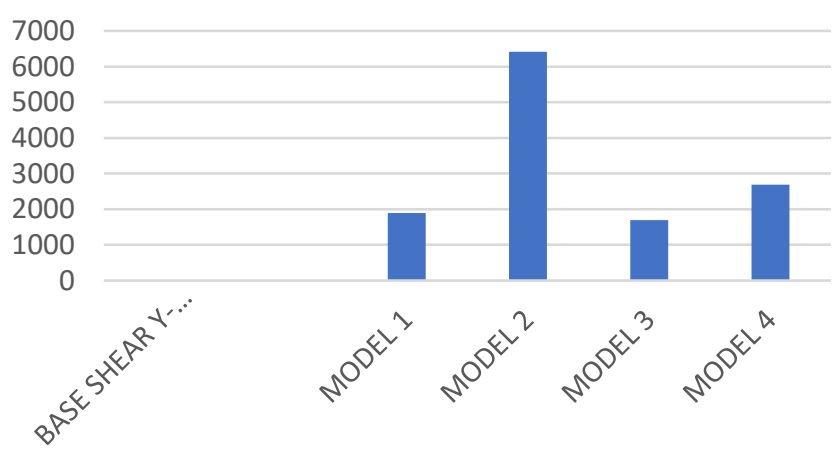

Graph 5 Base shear zone V
With the increase in the zones the base shear values is also found to be incrementing and is found to be highest in zonesV.

Base shear is highest in Model-2 for all the zones.

Base shear is found to be least in model-3 and model-1 for all zones along both thedirections.

The percentage reduction in base shear with respect to model-2 is $19.55 \%, 19.20 \%, 28.25 \%$ along $\mathrm{X}$ direction, similarly $29.59 \%, \quad 26.49 \%, \quad 41.96 \%$ along $\mathrm{Y}$ direction for model-1, model-3, model-4 respectively in zone $\mathrm{V}$.

\section{STOREY DISPLACEMENT}

The storey drift ratio for response spectrum analysis for all the stories, and for all the models are tabulated in the table along $\mathrm{X}$ direction and $\mathrm{Y}$ direction and graphs are plotted respectively for all seismic zone.

The incremental percentage in drift ratio is found to be similar for the seismic zones.

\begin{tabular}{|c|c|c|c|c|}
\hline \multicolumn{5}{|c|}{ Storey Displacement- SPEC-X (mm) } \\
\hline \multicolumn{5}{|c|}{ Zone II } \\
\hline Storey & Model 1 & Model 2 & Model-3 & Model-4 \\
\hline BASE & 0 & 0 & 0 & 0 \\
\hline 1 & 0.165 & 0.0168 & 0.0612 & 0.0834 \\
\hline 2 & 0.4158 & 0.0336 & 0.165 & 0.2244 \\
\hline 3 & 0.6768 & 0.051 & 0.2958 & 0.3954 \\
\hline 4 & 0.9288 & 0.069 & 0.4452 & 0.5844 \\
\hline 5 & 1.1652 & 0.087 & 0.6054 & 0.7794 \\
\hline 6 & 1.3824 & 0.1044 & 0.7716 & 0.9726 \\
\hline 7 & 1.578 & 0.1206 & 0.9378 & 1.158 \\
\hline 8 & 1.7496 & 0.1362 & 1.101 & 1.3302 \\
\hline 9 & 1.8948 & 0.15 & 1.2576 & 1.4862 \\
\hline 10 & 2.0106 & 0.1626 & 1.4046 & 1.6254 \\
\hline 11 & 2.0946 & 0.1734 & 1.5414 & 1.7472 \\
\hline 12 & 2.148 & 0.1824 & 1.665 & 1.8492 \\
\hline
\end{tabular}

\begin{tabular}{|c|c|c|c|c|}
\hline \multicolumn{5}{|c|}{ Storey Displacement- SPEC-Y (mm) } \\
\hline \multicolumn{5}{|c|}{ Zone II } \\
\hline Storey & Model 1 & Model 2 & Model 3 & Model 4 \\
\hline BASE & 0 & 0 & 0 & 0 \\
\hline 1 & 0.3708 & 0.0246 & 0.0642 & 0.0966 \\
\hline 2 & 0.7722 & 0.0498 & 0.1728 & 0.2514 \\
\hline 3 & 1.155 & 0.0768 & 0.3162 & 0.4482 \\
\hline 4 & 1.5108 & 0.105 & 0.4836 & 0.6714 \\
\hline 5 & 1.839 & 0.1326 & 0.6678 & 0.9084 \\
\hline 6 & 2.1378 & 0.1602 & 0.8622 & 1.149 \\
\hline 7 & 2.406 & 0.1866 & 1.062 & 1.3854 \\
\hline 8 & 2.6424 & 0.2118 & 1.2624 & 1.6128 \\
\hline 9 & 2.8446 & 0.2358 & 1.4592 & 1.8276 \\
\hline 10 & 3.0084 & 0.2574 & 1.65 & 2.0268 \\
\hline 11 & 3.1266 & 0.2778 & 1.833 & 2.211 \\
\hline 12 & 3.1968 & 0.2952 & 1.9998 & 2.3736 \\
\hline
\end{tabular}

Table 7 Displacement v/s storey along X \& Y direction for zone II 


\section{STORY DISPLACEMENT X- DIRECTION}

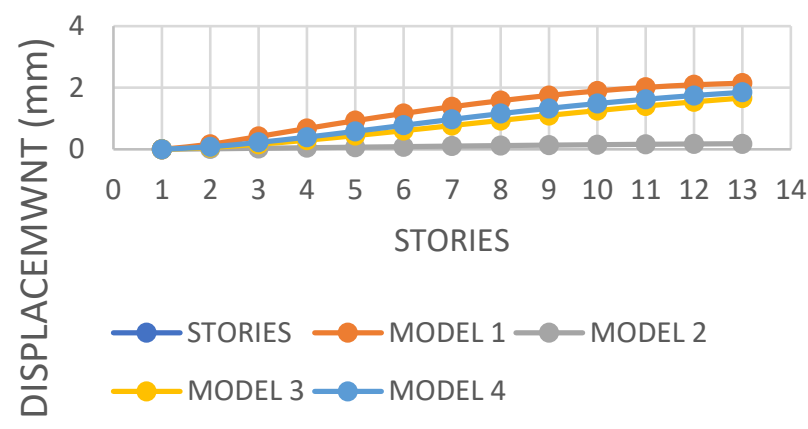

\section{STORY DISPLACEMENT Y- DIRECTION}

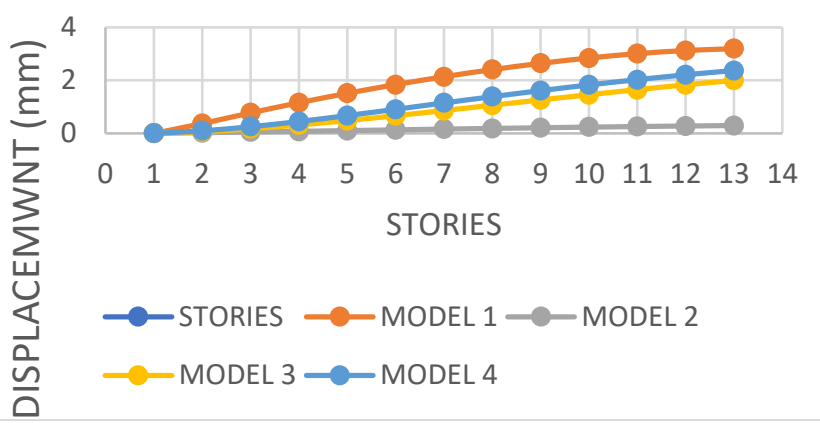

\section{Graph 6 Displacement v/s storey along X and $Y$} direction for zone II

\begin{tabular}{|c|c|c|c|c|}
\hline \multicolumn{5}{|c|}{ Storey Displacement- SPEC-Y (mm) } \\
\hline \multicolumn{5}{|c|}{ Zone } \\
\hline III \\
\hline Storey & Model 1 & Model 2 & Model 3 & Model 4 \\
\hline 1 & 0 & 0 & 0 & 0 \\
\hline 2 & 0.4944 & 0.0328 & 0.0856 & 0.1288 \\
\hline 3 & 1.0296 & 0.0664 & 0.2304 & 0.3352 \\
\hline 4 & 2.54 & 0.1024 & 0.4216 & 0.5976 \\
\hline 5 & 2.452 & 0.14 & 0.6448 & 0.8952 \\
\hline 6 & 2.8504 & 0.2136 & 1.1496 & 1.532 \\
\hline 7 & 3.208 & 0.2488 & 1.416 & 1.8472 \\
\hline 8 & 3.5232 & 0.2824 & 1.6832 & 2.1504 \\
\hline 9 & 3.7928 & 0.3144 & 1.9456 & 2.4368 \\
\hline 10 & 4.0112 & 0.3432 & 2.2 & 2.7024 \\
\hline 11 & 4.1688 & 0.3704 & 2.444 & 2.948 \\
\hline 12 & 4.2624 & 0.3936 & 2.6664 & 3.1648 \\
\hline
\end{tabular}

Table 8 Displacement v/s storey along X \& Y direction for zone III

\section{STORY DISPLACEMENT X- DIRECTION}

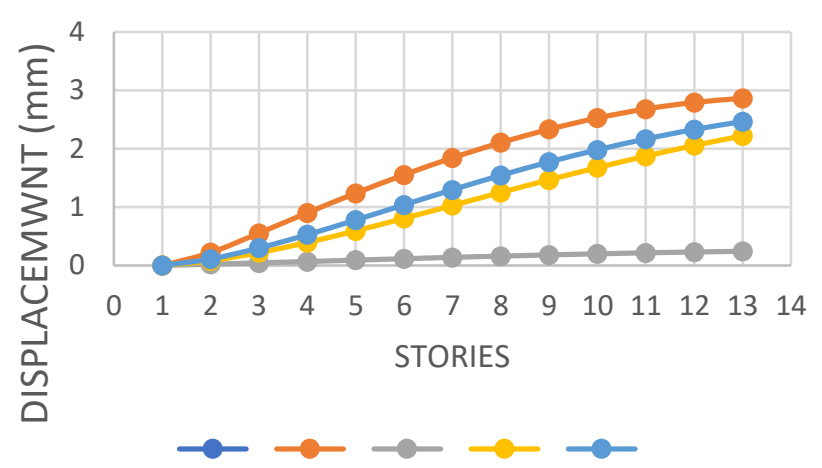

\section{STORY DISPLACEMENT Y- DIRECTION}

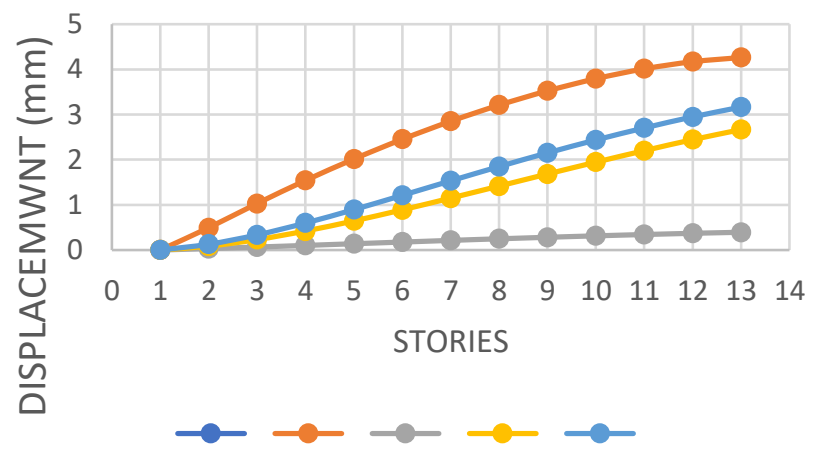

Graph 7 Displacement v/s storey along $X$ and $Y$ direction for zone III 


\begin{tabular}{|c|c|c|c|c|}
\hline \multicolumn{5}{|c|}{ Zone } \\
\hline \multicolumn{5}{|c|}{ IV } \\
\hline Storey Displacement- SPEC-X (mm) \\
\hline BASE & 0 & 0 & 0 & 0 \\
\hline 1 & 0.275 & 0.028 & 0.102 & 0.139 \\
\hline 2 & 0.693 & 0.056 & 0.275 & 0.374 \\
\hline 3 & 1.128 & 0.085 & 0.493 & 0.659 \\
\hline 4 & 1.548 & 0.115 & 0.742 & 0.974 \\
\hline 5 & 1.942 & 0.145 & 1.009 & 1.299 \\
\hline 6 & 2.304 & 0.174 & 1.286 & 1.621 \\
\hline 7 & 2.63 & 0.201 & 1.563 & 1.93 \\
\hline 8 & 2.916 & 0.227 & 1.835 & 2.217 \\
\hline 9 & 3.158 & 0.25 & 2.096 & 2.477 \\
\hline 10 & 3.351 & 0.271 & 2.341 & 2.709 \\
\hline 11 & 3.491 & 0.289 & 2.569 & 2.912 \\
\hline 12 & 3.58 & 0.304 & 2.775 & 3.082 \\
\hline
\end{tabular}

\begin{tabular}{|c|c|c|c|c|}
\hline \multicolumn{5}{|c|}{ Storey Displacement- SPEC-Y (mm) } \\
\hline \multicolumn{5}{|c|}{ IV } \\
\hline Storey & Model 1 & Model 2 & Model 3 & Model 4 \\
\hline BASE & 0 & 0 & 0 & 0 \\
\hline 1 & 0.618 & 0.041 & 0.107 & 0.161 \\
\hline 2 & 1.287 & 0.083 & 0.288 & 0.419 \\
\hline 3 & 1.925 & 0.128 & 0.527 & 0.747 \\
\hline 4 & 2.518 & 0.175 & 0.806 & 1.119 \\
\hline 5 & 3.065 & 0.221 & 1.113 & 1.514 \\
\hline 6 & 3.563 & 0.267 & 1.437 & 1.915 \\
\hline 7 & 4.01 & 0.311 & 1.77 & 2.309 \\
\hline 8 & 4.404 & 0.353 & 2.104 & 2.688 \\
\hline 9 & 4.741 & 0.393 & 2.432 & 3.046 \\
\hline 10 & 5.014 & 0.429 & 2.75 & 3.378 \\
\hline 11 & 5.211 & 0.463 & 3.055 & 3.685 \\
\hline 12 & 5.328 & 0.492 & 3.333 & 3.956 \\
\hline
\end{tabular}

Table 9 Displacement v/s storey along X \& Y direction for zone IV

\section{STORY DISPLACEMENT X- DIRECTION}

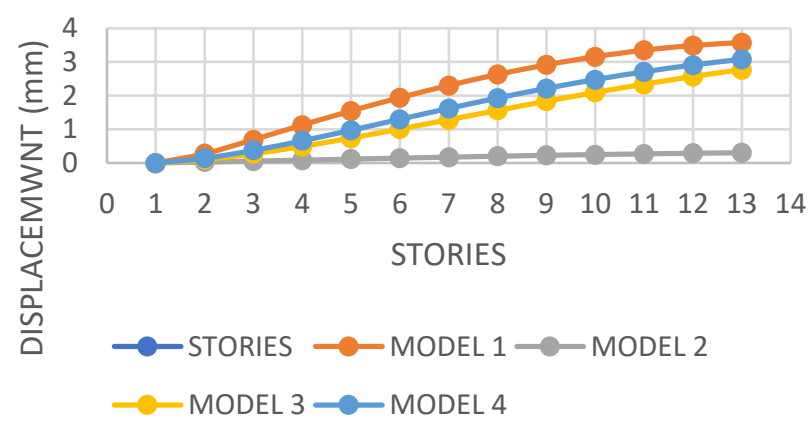

STORY DISPLACEMENT Y- DIRECTION

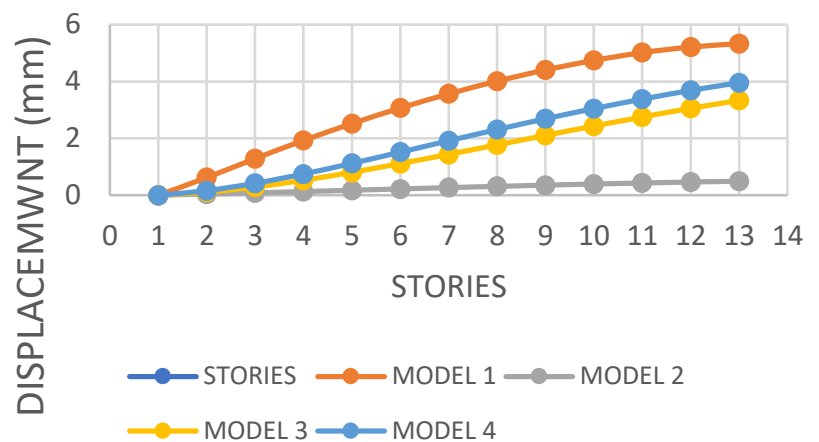

Graph 8 Displacement v/s storey along $X$ and $Y$ direction for zone IV

\begin{tabular}{|c|c|c|c|c|}
\hline \multicolumn{5}{|c|}{ Storey Displacement- SPEC-X (mm) } \\
\hline \multicolumn{5}{|c|}{ Zone V } \\
\hline Storey & Model 1 & Model 2 & Model-3 & Model-4 \\
\hline BASE & 0 & 0 & 0 & 0 \\
\hline 1 & 0.4125 & 0.042 & 0.153 & 0.2085 \\
\hline 2 & 1.0395 & 0.084 & 0.4125 & 0.561 \\
\hline 3 & 1.692 & 0.1275 & 0.7395 & 0.9885 \\
\hline 4 & 2.322 & 0.1725 & 1.113 & 1.461 \\
\hline 5 & 2.913 & 0.2175 & 1.5135 & 1.9485 \\
\hline 6 & 3.456 & 0.261 & 1.929 & 2.4315 \\
\hline 7 & 3.945 & 0.3015 & 2.3445 & 2.895 \\
\hline 8 & 4.374 & 0.3405 & 2.7525 & 3.3255 \\
\hline 9 & 4.737 & 0.375 & 3.144 & 3.7155 \\
\hline 10 & 5.0265 & 0.4065 & 3.5115 & 4.0635 \\
\hline 11 & 5.2365 & 0.4335 & 3.8535 & 4.368 \\
\hline 12 & 5.37 & 0.456 & 4.1625 & 4.623 \\
\hline
\end{tabular}

\begin{tabular}{|c|c|c|c|c|}
\hline \multicolumn{5}{|c|}{ Storey Displacement- SPEC-Y (mm) } \\
\hline \multicolumn{5}{|c|}{ Zone V } \\
\hline Storey & Model 1 & Model 2 & Model 3 & Model 4 \\
\hline BASE & 0 & 0 & 0 & 0 \\
\hline 1 & 0.927 & 0.0615 & 0.1605 & 0.2415 \\
\hline 2 & 1.9305 & 0.1245 & 0.432 & 0.6285 \\
\hline 3 & 2.8875 & 0.192 & 0.7905 & 1.1205 \\
\hline 4 & 3.777 & 0.2625 & 1.209 & 1.6785 \\
\hline 5 & 4.5975 & 0.3315 & 1.6695 & 2.271 \\
\hline 6 & 5.3445 & 0.4005 & 2.1555 & 2.8725 \\
\hline 7 & 6.015 & 0.4665 & 2.655 & 3.4635 \\
\hline 8 & 6.606 & 0.5295 & 3.156 & 4.032 \\
\hline 9 & 7.1115 & 0.5895 & 3.648 & 4.569 \\
\hline 10 & 7.521 & 0.6435 & 4.125 & 5.067 \\
\hline 11 & 7.8165 & 0.6945 & 4.5825 & 5.5275 \\
\hline 12 & 7.992 & 0.738 & 4.9995 & 5.934 \\
\hline
\end{tabular}

Table 10 Displacement v/s storey along X \& Y direction for zone $\mathrm{V}$ 


\section{STORY DISPLACEMENT X- DIRECTION}

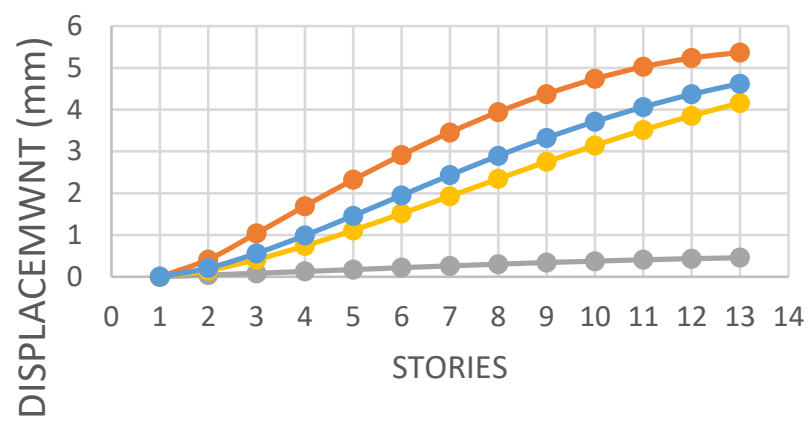

$\rightarrow \multimap-\bullet-\bullet$

\section{STORY DISPLACEMENT Y- DIRECTION}

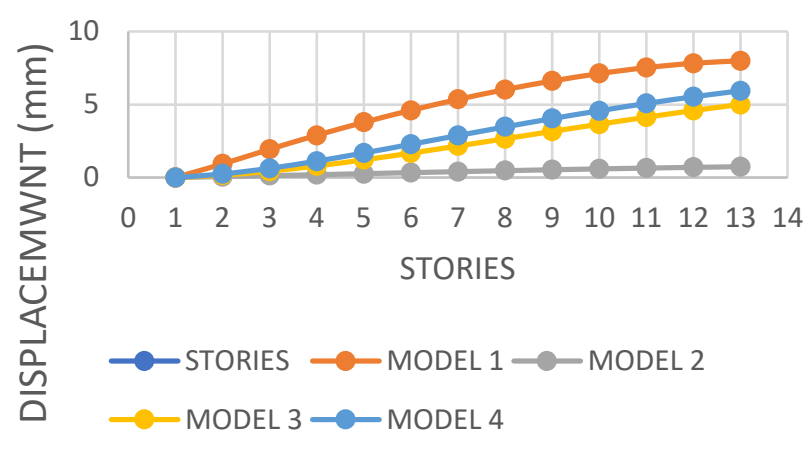

Graph 9 Displacement v/s storey along $Y$ direction for zone $\mathbf{V}$

In the dynamic response spectrum method of analysis, the storey displacements for all the stories, and for all the models are tabulated in the table along $\mathrm{X}$ direction and $\mathrm{Y}$ direction and graphs are plotted respectively for zone II, III, IV and $\mathrm{V}$ respectively.

Along X-Direction:

The maximum displacement obtained is $5.37 \mathrm{~mm}$ for model1 along Y-direction as shown in the table for zone V is within the permissible limits.

Storey Displacement is found to be highest in model-1 and is found to be least in model-2 in all the zones II, III, IV and $\mathrm{V}$.

The percentage reduction along X-direction for model-1, model-3 and model-4 is $8.49 \%, 10.95 \%$ and $9.86 \%$ respectively with respect to least displaced model ie., model2 for zone $\mathrm{V}$.

Along Y-Direction:

The maximum displacement obtained is $7.99 \mathrm{~mm}$ for model1 along Y-direction as shown in the table for zone V is within the permissible limits.

Storey Displacement is found to be highest in model-1 and is found to be least in model-2 in all the zones II, III, IV and $\mathrm{V}$.

The percentage reduction along Y-direction for model1 ,model-3 and model-4 is $9.32 \%, 14.76 \%$ and $12.44 \%$ respectively with respect to least displaced model ie., model-2 for zone $\mathrm{V}$.

\section{STOREY DRIFT}

The storey drift ratio for response spectrum analysis for all the stories, and for all the models are tabulated in the table along $\mathrm{X}$ direction and $\mathrm{Y}$ direction and graphs are plotted respectively for all seismic zone.

The incremental percentage in drift ratio is found to be similar for the seismic zones.

\begin{tabular}{|c|c|c|c|c|}
\hline \multicolumn{5}{|c|}{ Storey Drift- SPEC-X (mm) } \\
\hline \multicolumn{5}{|c|}{ Zone II } \\
\hline Storey & Model 1 & Model 2 & Model-3 & Model-4 \\
\hline $\mathrm{B}$ & 0 & 0 & 0 & 0 \\
\hline 1 & 0.0000522 & 0.0000054 & 0.0000192 & 0.0000264 \\
\hline 2 & 0.000084 & 0.000006 & 0.0000348 & 0.0000474 \\
\hline 3 & 0.000087 & 0.000006 & 0.0000438 & 0.0000576 \\
\hline 4 & 0.0000846 & 0.000006 & 0.0000498 & 0.0000636 \\
\hline 5 & 0.0000798 & 0.000006 & 0.000054 & 0.0000654 \\
\hline 6 & 0.0000744 & 0.000006 & 0.0000558 & 0.0000654 \\
\hline 7 & 0.0000684 & 0.0000054 & 0.0000564 & 0.000063 \\
\hline 8 & 0.0000606 & 0.0000054 & 0.0000552 & 0.0000588 \\
\hline 9 & 0.0000528 & 0.0000048 & 0.0000528 & 0.000054 \\
\hline 10 & 0.0000432 & 0.0000042 & 0.0000504 & 0.000048 \\
\hline 11 & 0.0000318 & 0.0000036 & 0.0000468 & 0.0000426 \\
\hline 12 & 0.0000204 & 0.000003 & 0.0000444 & 0.0000366 \\
\hline \multicolumn{5}{|c|}{ Storey Drift-SPEC- Y (mm) } \\
\hline \multicolumn{5}{|c|}{ Zone II } \\
\hline Storey & Model 1 & Model 2 & Model-3 & Model-4 \\
\hline $\mathrm{B}$ & 0 & 0 & 0 & 0 \\
\hline 1 & 0.0001176 & 0.0000078 & 0.0000204 & 0.0000306 \\
\hline 2 & 0.0001338 & 0.0000084 & 0.0000366 & 0.0000516 \\
\hline 3 & 0.0001284 & 0.000009 & 0.000048 & 0.000066 \\
\hline 4 & 0.0001212 & 0.0000096 & 0.0000564 & 0.000075 \\
\hline 5 & 0.000114 & 0.0000096 & 0.0000618 & 0.0000798 \\
\hline 6 & 0.0001074 & 0.0000096 & 0.0000654 & 0.0000816 \\
\hline 7 & 0.0001002 & 0.000009 & 0.0000672 & 0.000081 \\
\hline 8 & 0.0000918 & 0.0000084 & 0.0000678 & 0.000078 \\
\hline 9 & 0.0000816 & 0.0000084 & 0.0000672 & 0.0000744 \\
\hline 10 & 0.0000684 & 0.0000078 & 0.0000648 & 0.0000696 \\
\hline 11 & 0.000051 & 0.0000072 & 0.0000624 & 0.0000642 \\
\hline 12 & 0.00003 & 0.000006 & 0.00006 & 0.0000588 \\
\hline
\end{tabular}

Table 11 Drift ratio v/s storey along $\mathrm{X} \& \mathrm{Y}$ direction for zone II 


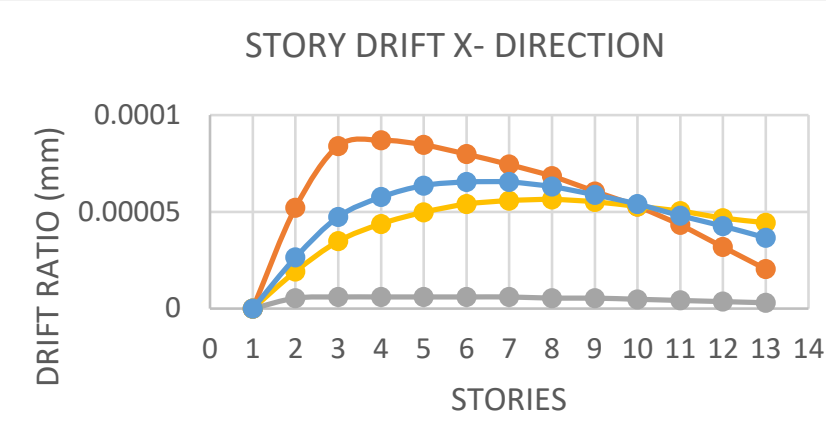

$\multimap$ STORIES $\multimap$ MODEL $1 \multimap$ MODEL 2

$\longrightarrow$ MODEL $3 \longrightarrow$ MODEL 4

STORY DRIFT Y- DIRECTION

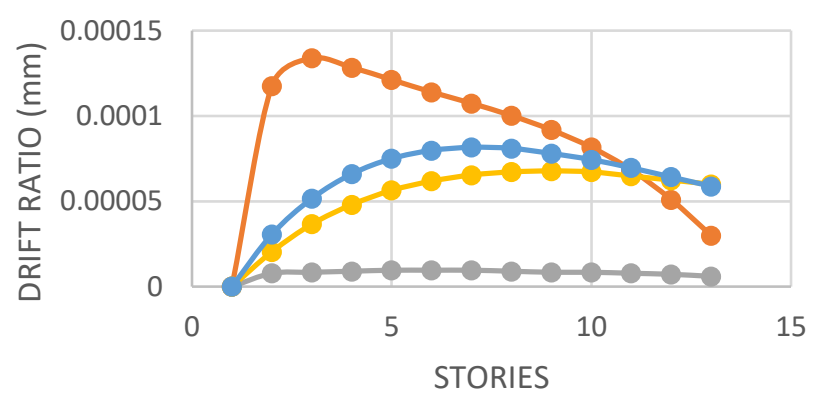

$\longrightarrow$ STORIES $\longrightarrow$ MODEL $1 \longrightarrow$ MODEL 2

$\longrightarrow$ MODEL $3 \multimap$ MODEL 4

Graph 10 Drift ratio v/s storey along $Y$ direction for zone II

\begin{tabular}{|r|l|l|l|l|}
\hline \multicolumn{5}{|c|}{ Storey $\begin{array}{c}\text { Zone } \\
\text { III }\end{array}$} \\
\hline \multicolumn{5}{|c|}{ SPEC-X (mm) } \\
\hline Storey & Model 1 & Model 2 & Model-3 & Model-4 \\
\hline B & 0 & 0 & 0 & 0 \\
\hline 1 & 0.0000696 & 0.0000072 & 0.0000256 & 0.0000352 \\
\hline 2 & 0.000112 & 0.000008 & 0.0000464 & 0.0000632 \\
\hline 3 & 0.000116 & 0.000008 & 0.0000584 & 0.0000768 \\
\hline 4 & 0.0001128 & 0.000008 & 0.0000664 & 0.0000848 \\
\hline 5 & 0.0001064 & 0.000008 & 0.000072 & 0.0000872 \\
\hline 6 & 0.0000992 & 0.000008 & 0.0000744 & 0.0000872 \\
\hline 7 & 0.0000912 & 0.0000072 & 0.0000752 & 0.000084 \\
\hline 8 & 0.0000808 & 0.0000072 & 0.0000736 & 0.0000784 \\
\hline 9 & 0.0000704 & 0.0000064 & 0.0000704 & 0.000072 \\
\hline 10 & 0.0000576 & 0.0000056 & 0.0000672 & 0.000064 \\
\hline 11 & 0.0000424 & 0.0000048 & 0.0000624 & 0.0000568 \\
\hline 12 & 0.0000272 & 0.000004 & 0.0000592 & 0.0000488 \\
\hline
\end{tabular}

\begin{tabular}{|r|l|c|c|c|}
\hline \multicolumn{5}{|c|}{$\begin{array}{c}\text { Zone } \\
\text { III }\end{array}$} \\
\hline \multicolumn{5}{|c|}{ Storey Drift-SPEC- Y (mm) } \\
\hline Storey & Model 1 & Model 2 & Model-3 & Model-4 \\
\hline B & 0 & 0 & 0 & 0 \\
\hline 1 & 0.0001568 & 0.0000104 & 0.0000272 & 0.0000408 \\
\hline 2 & 0.0001784 & 0.0000112 & 0.0000488 & 0.0000688 \\
\hline 3 & 0.0001712 & 0.000012 & 0.000064 & 0.000088 \\
\hline 4 & 0.0001616 & 0.0000128 & 0.0000752 & 0.0001 \\
\hline 5 & 0.000152 & 0.0000128 & 0.0000824 & 0.0001064 \\
\hline 6 & 0.0001432 & 0.0000128 & 0.0000872 & 0.0001088 \\
\hline 7 & 0.0001336 & 0.000012 & 0.0000896 & 0.000108 \\
\hline 8 & 0.0001224 & 0.0000112 & 0.0000904 & 0.000104 \\
\hline 9 & 0.0001088 & 0.0000112 & 0.0000896 & 0.0000992 \\
\hline 10 & 0.0000912 & 0.0000104 & 0.0000864 & 0.0000928 \\
\hline 11 & 0.000068 & 0.0000096 & 0.0000832 & 0.0000856 \\
\hline 12 & 0.00004 & 0.000008 & 0.00008 & 0.0000784 \\
\hline 12
\end{tabular}

Table 12 Drift ratio v/s storey along $\mathrm{X} \& \mathrm{Y}$ direction for zone III

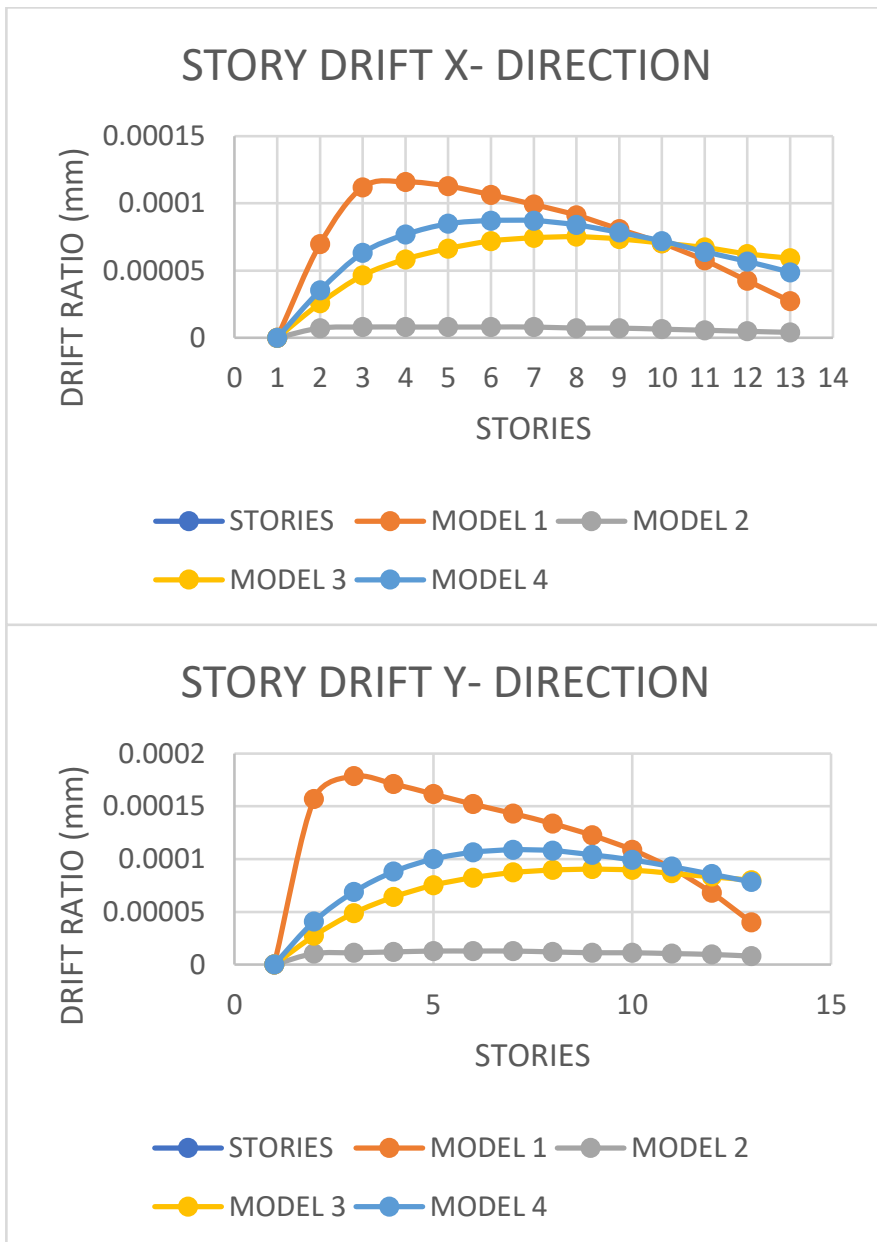

Graph 11 Drift ratio v/s storey along $X$ and $Y$ direction for zone III 


\begin{tabular}{|r|l|l|l|l|}
\hline \multicolumn{5}{|c|}{$\begin{array}{c}\text { Storey } \\
\text { IV }\end{array}$} \\
\hline \multicolumn{5}{|c|}{ Drift- SPEC-X $(\mathrm{mm})$} \\
\hline Storey & Model 1 & Model 2 & Model-3 & Model-4 \\
\hline B & 0 & 0 & 0 & 0 \\
\hline 1 & 0.000087 & 0.000009 & 0.000032 & 0.000044 \\
\hline 2 & 0.00014 & 0.00001 & 0.000058 & 0.000079 \\
\hline 3 & 0.000145 & 0.00001 & 0.000073 & 0.000096 \\
\hline 4 & 0.000141 & 0.00001 & 0.000083 & 0.000106 \\
\hline 5 & 0.000133 & 0.00001 & 0.00009 & 0.000109 \\
\hline 6 & 0.000124 & 0.00001 & 0.000093 & 0.000109 \\
\hline 7 & 0.000114 & 0.000009 & 0.000094 & 0.000105 \\
\hline 8 & 0.000101 & 0.000009 & 0.000092 & 0.000098 \\
\hline 9 & 0.000088 & 0.000008 & 0.000088 & 0.00009 \\
\hline 10 & 0.000072 & 0.000007 & 0.000084 & 0.00008 \\
\hline 11 & 0.000053 & 0.000006 & 0.000078 & 0.000071 \\
\hline 12 & 0.000034 & 0.000005 & 0.000074 & 0.000061 \\
\hline
\end{tabular}

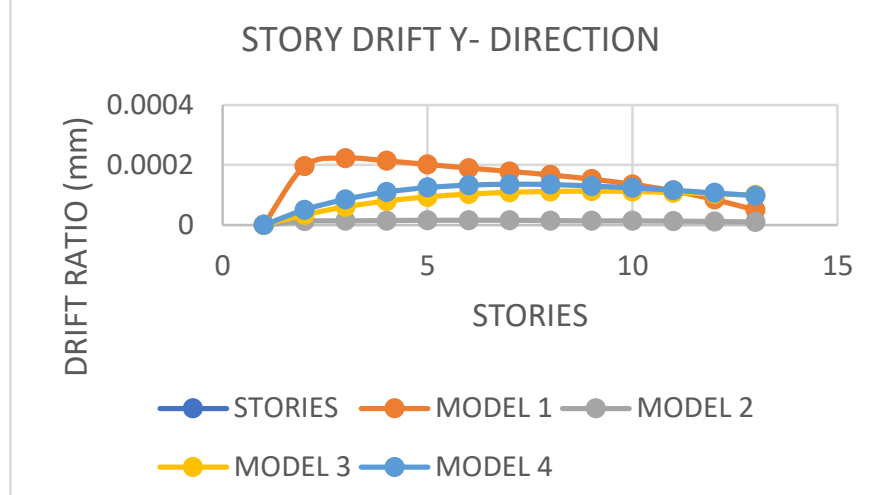

\begin{tabular}{|c|c|c|c|c|}
\hline \multicolumn{5}{|c|}{ Storey Drift-SPEC- Y (mm) } \\
\hline \multicolumn{5}{|c|}{$\begin{array}{c}\text { Zone } \\
\text { IV } \\
\end{array}$} \\
\hline Storey & Model 1 & Model 2 & Model-3 & Model-4 \\
\hline $\mathrm{B}$ & 0 & 0 & 0 & 0 \\
\hline 1 & 0.000196 & 0.000013 & 0.000034 & 0.000051 \\
\hline 2 & 0.000223 & 0.000014 & 0.000061 & 0.000086 \\
\hline 3 & 0.000214 & 0.000015 & 0.00008 & 0.00011 \\
\hline 4 & 0.000202 & 0.000016 & 0.000094 & 0.000125 \\
\hline 5 & 0.00019 & 0.000016 & 0.000103 & 0.000133 \\
\hline 6 & 0.000179 & 0.000016 & 0.000109 & 0.000136 \\
\hline 7 & 0.000167 & 0.000015 & 0.000112 & 0.000135 \\
\hline 8 & 0.000153 & 0.000014 & 0.000113 & 0.00013 \\
\hline 9 & 0.000136 & 0.000014 & 0.000112 & 0.000124 \\
\hline 10 & 0.000114 & 0.000013 & 0.000108 & 0.000116 \\
\hline 11 & 0.000085 & 0.000012 & 0.000104 & 0.000107 \\
\hline 2 & 0.00005 & 0.00001 & 0.0001 & 0.000098 \\
\hline
\end{tabular}

Graph 12 Drift ratio v/s storey along $X$ and $Y$ direction for zone IV

\begin{tabular}{|r|l|l|l|l|}
\hline \multicolumn{5}{|c|}{ Storey Drift- SPEC-X (mm) } \\
\hline \multicolumn{5}{|c|}{ Zone V } \\
\hline Storey & Model 1 & Model 2 & Model-3 & Model-4 \\
\hline B & 0 & 0 & 0 & 0 \\
\hline 1 & 0.0001305 & 0.0000135 & 0.000048 & 0.000066 \\
\hline 2 & 0.00021 & 0.000015 & 0.000087 & 0.0001185 \\
\hline 3 & 0.0002175 & 0.000015 & 0.0001095 & 0.000144 \\
\hline 4 & 0.0002115 & 0.000015 & 0.0001245 & 0.000159 \\
\hline 5 & 0.0001995 & 0.000015 & 0.000135 & 0.0001635 \\
\hline 6 & 0.000186 & 0.000015 & 0.0001395 & 0.0001635 \\
\hline 7 & 0.000171 & 0.0000135 & 0.000141 & 0.0001575 \\
\hline 8 & 0.0001515 & 0.0000135 & 0.000138 & 0.000147 \\
\hline 9 & 0.000132 & 0.000012 & 0.000132 & 0.000135 \\
\hline 10 & 0.000108 & 0.0000105 & 0.000126 & 0.00012 \\
\hline 11 & 0.0000795 & 0.000009 & 0.000117 & 0.0001065 \\
\hline 12 & 0.000051 & 0.0000075 & 0.000111 & 0.0000915 \\
\hline \hline \multicolumn{5}{|c|}{ Storey Drift-SPEC- Y (mm) } \\
\hline \multicolumn{5}{|c|}{ Zone V } \\
\hline Storey & Model 1 & Model 2 & Model-3 & Model-4 \\
\hline B & 0 & 0 & 0 & 0 \\
\hline 1 & 0.000294 & 0.0000195 & 0.000051 & 0.0000765 \\
\hline 2 & 0.0003345 & 0.000021 & 0.0000915 & 0.000129 \\
\hline 3 & 0.000321 & 0.0000225 & 0.00012 & 0.000165 \\
\hline 4 & 0.000303 & 0.000024 & 0.000141 & 0.0001875 \\
\hline 5 & 0.000285 & 0.000024 & 0.0001545 & 0.0001995 \\
\hline 6 & 0.0002685 & 0.000024 & 0.0001635 & 0.000204 \\
\hline 7 & 0.0002505 & 0.0000225 & 0.000168 & 0.0002025 \\
\hline 8 & 0.0002295 & 0.000021 & 0.0001695 & 0.000195 \\
\hline 9 & 0.000204 & 0.000021 & 0.000168 & 0.000186 \\
\hline 10 & 0.000171 & 0.0000195 & 0.000162 & 0.000174 \\
\hline 11 & 0.0001275 & 0.000018 & 0.000156 & 0.0001605 \\
\hline 12 & 0.000075 & 0.000015 & 0.00015 & 0.000147 \\
\hline
\end{tabular}

\footnotetext{
$\longrightarrow$ STORIES $\longrightarrow$ MODEL $1 \multimap$ MODEL 2

-MODEL $3 \longrightarrow$ MODEL 4
}

Table 14 Drift ratio v/s storey along X\&Y direction for zone $\mathrm{V}$ 


\section{STORY DRIFT X- DIRECTION}

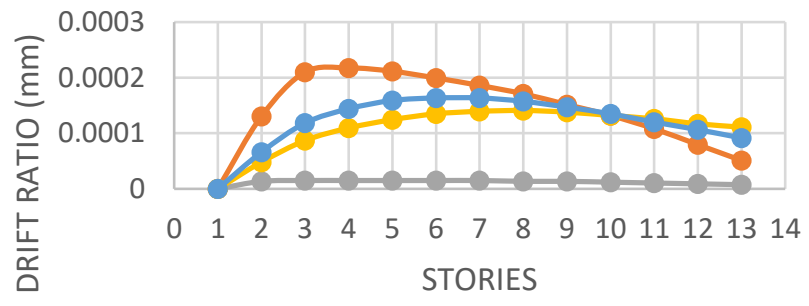

$\longrightarrow$ STORIES $\longrightarrow$ MODEL $1 \multimap$ MODEL 2

$\longrightarrow$ MODEL $3 \multimap$ MODEL 4

STORY DRIFT Y- DIRECTION

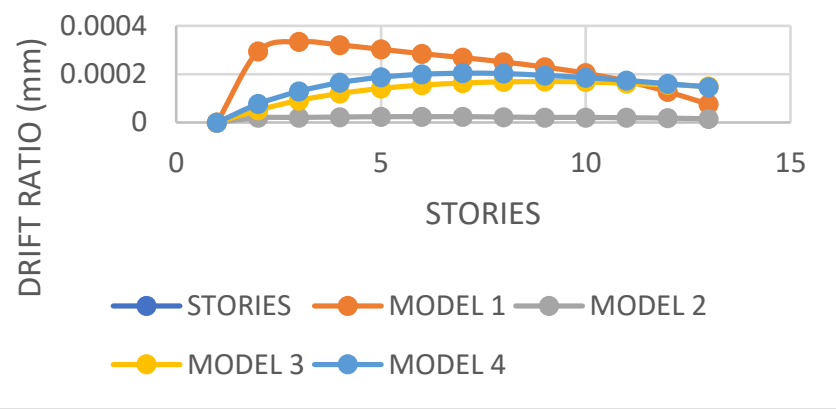

Graph 13 Drift ratio v/s storey along $X$ and $Y$ direction for zone $V$

The storey drift ratio for all the stories, and for all the models are tabulated in the table along $\mathrm{X}$ direction and $\mathrm{Y}$ direction and graphs are plotted respectively for zones II, III, IV and V respectively.

The maximum Drift ratio obtained at top storey is found to be 0.000111 along X-direction in model-3 and 0.00015 along Y-direction in model-3 as shown in the table for zone V.

Storey Drift ratio is found to be highest in model-3 and model-3 along $\mathrm{X}$ and $\mathrm{Y}$ directions respectively for all the zones II, III, IV and V.

Similarly Drift ratio is found to be least in model-2 and model-2 along $\mathrm{X}$ and $\mathrm{Y}$ directions respectively for all the zones II, III, IV and V.

The percentage reduction along X-direction for model-1, model-3 and model-4 is

$14.71 \%, 6.76 \%$ and $8.20 \%$ respectively with respect to maximum displaced model ie., model- 2 for zone V.

Similarly the percentage reduction along $\mathrm{Y}$ direction for model-1, model-3 and model-4 is $20.00 \%, 10.00 \%$ and $10.20 \%$ respectively with respect to maximum displaced model ie., model-2 for zoneV.

\section{CONCLUSION}

From the results and discussions following conclusions are made with respect to dynamic response spectrum analysis of RCC Framed structure with and without shear wall.

$>$ The maximum time period obtained is $1.658 \mathrm{sec}$ for model $1 \&$ minimum time period is $0.274 \mathrm{sec}$ for model-2, hence from this analysis models 2 is more stiffer than othermodels in all zones.

The displacement at the top storey is more, in all zonemodels.

Models with shear wall shows reduction in displacement, there by models 2 shows least displacement compared to other models.

By increasing seismic zones gradually displacements also increase in response spectrum method ofanalysis.

The displacements in the shear wall model-2 is less as compared to other models.

The percentage reduction for model-1, model-3 and model-4 is $8.49 \%, 10.95 \%$ and $9.86 \%$ respectively with respect to least displaced model ie., model-2 for zone V.

The displacement is increased gradually from bottom to topstory.

The storey drift is gradually reduced in model 3 \& model 4 .

The percentage reduction for model-1, model- 3 and model4 is $14.71 \%, 6.76 \%$ and $8.20 \%$ respectively with respect to maximum displaced model ie., model- 2 for zone $\mathrm{V}$

Drift ratio is least in model- 3 and model- 4 along $\mathrm{X}$ and $\mathrm{Y}$ directions for all the zones.

The percentage of increment in the displacement and drift ratio is same for all the seismic zones.

The base shear values are incrementing in all the zones \& shows highest base shear value for zoneV

Base shear is highest in Model-2 for all thezones.

Considering the construction time factor, with shear wall structure need more time to execution,however proper workmanship needs to be followed for better structural behavior.

\section{REFERENCES}

[1] Jalali and F. Dashti"Nonlinear Behavior of Reinforced Concrete Shear Walls Using Macro Model"'Engineering Structures32(9):29592968 - September2010.

[2] Hamdy H. A and Abd-el-rahim, "Role of shear walls in high rise buildings" journal of engineering sciences, vol. (55) no.1 March2010.

[3] A Murali Krishna, Dr. E Arunakanthi“Optimum Location of Different Shapes of Shear Walls in Unsymmetrical High Rise Buildings" International Journal of Engineering Research \& Technology2014.

[4] M.Pavani, G.NageshKumar,Dr.Sandeep Pingale "Shear Wall Analysis and Design Optimization In Case of High Rise Buildings Using Etabs (software)" International Journal of Scientific \& Engineering Research2015.

[5] Mallika.K , Nagesh Kumar.G "Analysis of Shear Wall in High Rise Unsymmetrical Building Using Etabs” International Journal of Innovative Research in Science, Engineering and Technology Vol. 5, Issue 11, November 2016.

[6] Shruti Badami, M. R. Suresh "A Study on Behavior of Structural Systems for Tall Buildings Subjected To Lateral Loads" International journal of civil engineeringVolume 03, Issue 07 (July2014)

[7] Axay Thapa \&Sajal Sarkar "Comparative study of multi-storied RCC building with and without shear wall'International journal of civil engineering Vol. 6, Issue 2, February-March 2017.

[8] Sylviya B, P. Eswaramoorthi “Analysis of RCC Building with Shear Walls at Various Locations and In Different Seismic Zones" International Journal of Innovative Technology and Exploring Engineering, Volume-8 Issue-2, December, 2018.

[9] MD. Maksudul Haque, Md. HasibulhasanRahat, “ Numerical analysis of high rice RCC buildings with shear walls having opening of different shapes" International Journal of Advances in Mechanical 
and Civil Engineering, Volume- 5, Issue-3,Jun.-2018

[10] N.Subramanian"Design of Reinforced Structures"Oxfordpublications

[11] Bungale S. Taranath" Structural Analysis And Design Of Tall Buildings"CRC presspublications

\section{RRFERENCES CODE OF PRACTICE}

[1] IS 456 (2000): Plain and Reinforced Concrete - Code of Practice.

[2] IS 875 - I (1987): Code of Practice for Design Loads (Other Than Earthquake) For Buildings and Structures, Part 1: Dead Loads.

[3] IS 875 - II (1987): Code of Practice for Design Loads (Other Than Earthquake) For Buildings and Structures, Part 2: Imposed Loads.

[4] IS 875 - III (2015): Code of Practice for Design Loads (Other than Earthquake) for Buildings and Structures, Part 3: Wind Loads.

[5] IS 1893- Part 1 (2016): Criteria for Earthquake Resistant Design of Structures, Part 1: General Provisions and Buildings

[6] IS 1893(Part 1)-2002: Criteria for earthquake resistant design of structures: Part 1: General Provisions and buildings 